\title{
Téoros
}

Revue de recherche en tourisme

\section{Économie du tourisme. Éléments bibliographiques}

\section{Lyne Schmidt}

Volume 7, numéro 3, novembre 1988

Économie du tourisme

URI : https://id.erudit.org/iderudit/1080387ar

DOI : https://doi.org/10.7202/1080387ar

Aller au sommaire du numéro

Éditeur(s)

Université du Québec à Montréal

ISSN

0712-8657 (imprimé)

1923-2705 (numérique)

Découvrir la revue

Citer ce document

Schmidt, L. (1988). Économie du tourisme. Éléments bibliographiques. Téoros, 7(3), 54-55. https://doi.org/10.7202/1080387ar d'utilisation que vous pouvez consulter en ligne.

https://apropos.erudit.org/fr/usagers/politique-dutilisation/ 


\section{Économie du tourisme Éléments \\ bibliographiques}

La liste bibliographique suivante présente quelques références pour vous aider dans vos recherches sur l'Economie du tourisme et ses sujets connexes; tourisme international, calcul de retombées et la demande touristique. Étant donné l'étendue et la diversité du sujet, il est impossible de prétendre à l'exhaustivité dans ce cadre limité. La liste est donc sélective. Pour plus d'informations et pour consulter ces documents, le personnel du Centre d'études du tourisme (515, rue SteCatherine ouest, bur. 6600 à Montréal, tél.: (514) 282-8516) est à votre disposition.

* Madame Lyne Schmidt es! technicienne en documen tation au Centre d'ettudes du tourisme.

\section{Général}

BARETJE, R. et DEFERT, P., Aspects Économiques du tourisme, Paris: BergerLevreault, 1972, 355 p. (ECO-72.5794).

GUIBILATO, Gérard, Economie touristique, Suisse: Delta-Spès, 1983, 185 p. (ECO-83.25834).

LANQUAR, Robert, L'économie du tourisme, Paris: PUF, 1983, 127 p. (Que SaisJe? 2065) (ECO-83.22812).

SESSA, Alberto, Elements of Tourism Economics, Rome: Catal, 1983, 186 p. (ECO-83.23017).

\section{Tourisme international}

ANNALS OF TOURISM RESEARCH, Vol. 9, No 1 (1982), no spécial, The Economics of International Tourism, $\mathrm{pp}$. 1-140.

DE KADT, Emanuel, Tourisme. Passeport pour le développement, Economica, 1979. 345 p. (INT(DEV)-79.24936).

ENGLISH, Philip E., La grande évasion: un examen du tourisme Nord-Sud, Ottawa: Institut Nord-Sud, 1986, 99 p. (INT. 86.25410).

JENKINS, C.L., The Use of Investment $/ \mathrm{m}$ centives for Tourism Projects in Developing Countries, in Tourism Management, Vol. 3, No 2 (juin 1982), pp. 91-97.

LEATHERS, Charles G., MISIOLEK, Walters, Cost-Benefit Analysis in Planning for Tourism Development: The Special Problem of Socio-Cultural Cost, in Tourism Recreation Research, Vol. XI, No 2 (1986), pp. 85-90.

LOEB, Peter D., Intermational Travel to the United States. An Econometric Evaluation, in Annals of Tourism Research, Vol. 9, No 1 (1982), pp. 7-20.

ORGANISATION MONDIALE DU TOURISME, Les répercussions du tourisme international sur le développement ́́conomique dans les pays en voie de développement, Madrid: OMT, 1975, 219 p. (INT(ECO)-75.1821).

OMT, Conférence régionale africaine sur le tourisme et le développement économique, Madrid: OMT, 1978, $341 \mathrm{p}$. (AFR-ECO-78.6022).
OMT, Étude économique du tourisme mondial, Madrid: OMT (plusieurs années disponibles).

VELLAS, François, Économie et politique du tourisme international, Paris: Économica, 1985, 305 p. (ECO(INT)-85.25579).

WITT, Stephen F., MARTIN, Christine A., Econometric Models for Forecasting International Tourism Demand, in Journal of Travel Research, Vol. XXV, No 3 (Spring 1987), pp. 23-30.

\section{Méthodes de calcul des retombées économiques en tourisme}

ARCHER, Brian, The Uses and Abuses of Multipliers, Bangor (Angleterre), University of Wales Press, 1973, 14 p. (GRBPGA-ECO-73.15563).

ARCHER, Brian, Tourism Multipliers: The State of the Art, Bangor (Angleterre): University of Wales Press, 1977, 85 p. (GRB-ECO-77,3635).

ARCHER, Brian, The Anatomy of a Multiplier, Bangor (Angleterre): Institute of Economic Research, 1975, 14 p. (ECO74,11150 ).

BELLEROSE, Pierre, TREMBLAY, Pascal, Étude sur les différentes méthodes d'évaluation des dépenses touristiques et leurs difficultés d'application, Montréal: CET, 1985, 93 p. (ECO-85.24597).

BUREAU OF MANAGEMENT CONSULTING, Tourism Impact Model, Ottawa: Gouvernement du Canada, 1975,94 p. (CAN-ECO-75.14858).

BUREAU OF MANAGEMENT CONSULTING, Canadian Tourism Impact Studies: Policy and Planning Approaches, Ottawa: Gouvernement du Canada, 1975 , 17 p. (CAN-DEV-75, 14712).

CAMBAU, Denise, Les emplois directs et induits du tourisme en France, in Bulletin ITA, No 25, 7 juillet 1980, pp. 635-638.

CHADEE, D., MIECZ, Kourski Z., An Empirical Analysis of the Effects of the Exchange Rate on Canadian Tourism, in Journal of Travel Research, Vol. XXVI, No 1 (Summer 1987), pp. 13-17. 
CHAU, Peter, Definition of the Tourism Industry Boundaries, Ottawa: Tourisme Canada, 1984, 56 p. (CAN-GEN-84.30195).

COTE, Marcel, Le mythe des retombeies economiques, in Téoros, Vol. 3. No 2 (juillet 1984), pp. 2-6.

DAVIDSON, Lawrence S., SHAFFER, William A., A Discussion of Methods Employed in Analysing the Impact of Short-Term Entertainment Events, in Journal of Travel Research, Vol. XVIII, No 3 (Winter 1980), pp. 12-16.

DUFFIELD, Brian, Tourism: The Measurement of Economic and Social Impact, in Tourism Management, Vol. III, No 4 (December 1982), pp. 248-255.

FRECHTLING, Douglas $\mathrm{C}$, , Assessing the Impacts of Travel and Tourism, in Travel, Tourism and Hospitality Research, 1987, pp. 325-361 (GEN-87.30031).

FRECHTLING, Douglas C., Travel Economic Impact Model, Washington, D.C.: US Travel Data Center, 2 vol. (ECO.11783).

GAGNÉ, Irène; GOSSELIN, Karl, Situation de l'industrie touristique dans l'économie québécoise. Une analyse intersectorielle, Québec: Université Laval, 1978, 60 p. (QUE-ECO-78.24626).

LUNDBERG, Donald E., The Economic and Social Impacts of Tourism, in The Tourist Business, Boston: Cahners Books, 1979. pp. 119-152 (GEN-74.2055).

ORGANISATION MONDIALE DU TOURISME (OMT), La mesure des dépenses en matière de voyages et du tourisme, Madrid: OMT, 1985, 55 p. (ECO(MET)85.23996).

OMT, La place du tourisme dans les tableaux entrées-sorties de l'économie nationale, Madrid: OMT, 1985, 43 p. (ECO-85.25993).

OMT, Lignes directrices sur la construction d'un indice des prix touristiques, Madrid: OMT, 1985, 73 p. (MET(ECO)85.25987).

QUAYSON, Jojo, Tourism and Economic Growth in New-York CIty: A Case Study, Thèse de doctorat, University of Microfilms International, 1987, 147 p. (USA-NEYECO-87.30191).

RITCHIE, J.R. Brent, Some Critical Aspects of Measurement Theory and Practice in Travel Research, in Journal of Travel Research, Vol. XIV, No 1 (Summer 1975), pp. 1-10.
ROUX, J., Conception et expérimentation d'indices de prix dans le secteur touristique, application au produit neige, Aix-enProvence: CHET, 1988, 26 p. (ECO(TOH) (MET)-88.30261).

ROYER, Aline, L'évaluation économique d'événements à caractère touristique, Thèse de maîtrise en économie, Université de Montréal, 1983, 463 p. (ECO(EVE)83.24478).

SMERAL, Egon, Tourism Demand, Economic Theory and Econometrics: $\boldsymbol{A} n \mathrm{In}$ legrated Approach, in Journal of Travel Research, Vol. XXVI, No 4, Spring 1988, pp. $38-43$.

VAR, Turgut et Al., Tourism Multipliers Revisited, Aix-en-Provence: CHET, 1982, 34 p. (ECO-82.24070).

VAUGHAN, Roger, The Economic Impact of Tourism in Edinburgh and the Lothian Region, The Scottish Tourist Board, 1977. 49 p. (GRB-ECO-77.30193).

\section{La demande touristique}

ARCHER, Brian, Demand Forecasting and Estimation, in Travel, Tourism and Hospitality Research: A Handbook for Managers and Researchers, 1987, pp. 77-85 (GEN-87.30031).

BELLEROSE, Pierte, Le Québec et les flux touristiques: quelques données utiles, 1988, 89 p. (QUE-ECO-88.26540).

ORGANISATION MONDLALE DU TOURISME (OMT), Identification et évaluation des facteurs permanents et nouveaux et de motivations de vacances et de voyages qui influent sur la demande touristique actuelle (...), Madrid: OMT, 1985, 26 p. (SOC(ECO)-85.25989).

OMT, Les mouvements de personnes ou les réalités des flux touristiques, Madrid: OMT, 1984, 10 p. (ECO-84.23678).

\section{Divers}

BELLEROSE, P. et PELLETIER, J., Le libre-échange et le champ récréotouristique. Un secteur gagnant, $1988,60 \mathrm{p}$. (QUE(CAN)(ECO)-88.26418).

DEMERS, Jacques, Le développement touristique: notions et principes, Québec: Ministère du Tourisme, 1987, 342 p. (QUE(DEV)-87.26042).

DUBUC, Alain, Les congrès et les retombées économiques, in Téoros, Vol 4 , No 3 (novembre 1985), pp. 34-35.

FIGHIERA, Gian Carlo, Introduction à l'étude des dimensions économiques touristiques du marché des congrès, Aix-enProvence: CET, 1984, 59 p. (CON(ECO)84.24071).
LATIMER, H., The Concepts of Consumer and Producer Surpluses in Tourism, Aix-en-Provence: CHET, 1986, 41 p. (ECO-86.25873).

ORGANISATION MONDIALE DU TOURISME, Étude des encouragements a l'investissement touristique, Madrid: OMT, 1987, 59 p. (ECO-87.26084).

STAFFORD, Jean, BODSON, Paul, Éléments pour une economie du tourisme social, in Téoros, Vol, 1, No 3 (novembre 1982), pp. 22-25. 